\title{
Highly variable abiotic environment induced changes in taxonomic and functional composition of headwater chironomid assemblages within a small mountain range
}

\author{
Ildikó Szivák ${ }^{1,2,3}$, Arnold Móra ${ }^{3}$, Nikoletta Méhes ${ }^{4}$, Csaba Bereczki ${ }^{1}$, \\ Adrienne Ortmann-Ajkai ${ }^{1}$ and Zoltán Csabai ${ }^{1}$
}

With 2 figures, 5 tables and 1 appendix

\begin{abstract}
The spatial variability of Chironomidae larvae assemblages was investigated at 6 near-pristine, temperate headwaters in Hungary. Sites were located within a relatively small mountain range but belong to two different catchment areas characterized by highly variable abiotic conditions. We hypothesised there would be differences in taxonomic composition but not in functional composition between different catchment areas and aimed to assess the primary influencing spatial factors structuring the taxonomic and functional compositions of chironomid assemblages. The spatial distribution of chironomid assemblages was examined 4 times during a 1 year period at microhabitat to catchment scales. At each site, streambed morphology, physicochemical attribute, riparian vegetation, microclimate and hydrology data were collected. Three main traits (saprobic preference, stream zonation preference, functional feeding groups) were used to characterize the functional composition of chironomid assemblages. Sharp differences were detected in taxonomic composition between the two sides of the mountain range within a relatively small spatial distance and moderate, but statistically significant differences in functional composition between catchments. The observed spatial changes in taxonomic and functional composition of midges accompanied changes in physicochemical characteristics, riparian vegetation, microclimate and altitude. Internal microhabitat heterogeneity also played a major role in structuring the taxonomic and the functional patterns of chironomid assemblages.
\end{abstract}

Key words: headwater Chironomidae, small mountain range, habitat heterogeneity, spatial variation, taxonomic and functional composition, multivariate approaches.

\section{Introduction}

According to the River Continuum Concept (RCC), longitudinal shifts of macroinvertebrate assemblages are influenced by changing environmental conditions from spring to mouth (Vannote et al. 1980). At a finer scale, community shifts are subtle within the same reach in permanent streams (Feminella 1996, Progar \& Moldenke 2002) due to the relatively slighter environmental gradient. Within a small geographi-

\footnotetext{
Authors' addresses:

${ }^{1}$ University of Pécs, Department of Ecology and Hydrobiology, Ifjúság útja 6., H-7624, Pécs, Hungary

${ }^{2}$ University of Pécs, Insitute of Biology, Ifjúság útja 6., H-7624, Pécs, Hungary

${ }^{3}$ Hungarian Academy of Sciences, Centre for Ecological Research, Balaton Limnological

Institute, Klebelsberg Kuno u. 3., H-8237, Tihany, Hungary

${ }^{4}$ University of West Hungary, Department of Chemistry and Environmental Sciences, Károlyi Gáspár tér 4., H-9700,

Szombathely, Hungary
} 
cal range, relatively small differences are assumed between assemblages of permanent stream sections that are at the same longitudinal position than along the longitudinal continuum (Lindegaard \& Brodersen 1995, Puntí et al. 2009, Raposeiro et al. 2011). On the other hand, the Habitat Templet Theory emphasises the important role of abiotic habitat features and their spatial and temporal variability in structuring communities and in the selection of traits that maximize species fitness (Southwood 1977, Townsend \& Hildrew 1994, Poff 1997). In headwater streams, the community composition is influenced by both broad scale constraints (e.g. geology and climate) and local scale drivers (e.g. physicochemical characteristics, streambed morphology) (Poff \& Ward 1990), which could be highly variable within a small geographical range. Additionally, high internal physical heterogeneity exists within headwater reaches compared to downstream sections (Gooderham et al. 2007). This kind of abiotic heterogeneity could have fundamental importance in shaping headwater communities through providing refuges against temporal disturbances like floods and droughts (Townsend 1989). Gooderham et al. (2007) also pointed out that small headwaters are directly influenced by atmospheric, bedrock, soil and riparian features.

The non-biting midges (Diptera: Chironomidae) are the most widely distributed, most diverse, and often the most abundant family of the whole macroinvertebrate spectrum in lotic ecosystems (Giller \& Malmqvist 1998), and they occupy a wide variety of habitats (Pinder 1995). Chironomids are indicators of anthropogenic impact as well as natural environmental gradients, since most genera include species with different ecological traits (Calle-Martínez \& Casas 2006, Marziali et al. 2010, Lencioni et al. 2012, Milošević et al. 2012, Móra \& Szivák 2012). Thus, the analysis of their larval species composition alone can be used to differentiate sites with varying environmental conditions in streams and rivers (Armitage \& Blackburn 1985, Cranston 1995, Orendt 2000, Móra et al. 2008).

Several studies have aimed to identify the driving forces that structure the chironomid assemblages in headwaters at different spatial scales (e.g. Heino 2005, Raunio et al. 2011, Rosa et al. 2011). However, these works mainly focus on the effects of extreme environmental conditions such as droughts (Calle-Martínez \& Casas 2006, Puntí et al. 2007), high altitude (Lencioni $\&$ Rossaro 2005), location in oceanic islands (Raposeiro et al. 2011) or the effect of large environmental gradients (Heino \& Mykrä 2008, Puntí et al. 2009,
Roque et al. 2010, Siqueira et al. 2009). At broader spatial scales, the distribution and diversity of lotic chironomid larval assemblages are constrained mainly by the geographic position of reaches, stream size, land use, geology, thermal regime and slope (CalleMartínez \& Casas 2006, Puntí et al. 2007, 2009, Raposeiro et al. 2011). At the reach scale, the particle size of substrata, water depth and current velocity have the most important role in structuring chironomid assemblages (Lencioni \& Rossaro 2005, Rosa et al. 2011). Based on the metacommunity patterns of Chironomidae larvae in boreal calcareous streams within the same drainage system, structures of assemblages show weak relationship with any local scale environmental variables (Heino 2005).

How chironomid assemblages respond to highly variable abiotic environmental conditions (i.e. bedrock geology) within small geographical distances, for example within the same mountain range or catchment, remains unknown. However, it is well known that invertebrates respond quickly to disturbances and environmental heterogeneity at small spatial scales (Townsend 1989). Chironomids are a very diverse group regarding functional traits, which make the species successful colonizers of all types of habitats. Even so, little information is available about the role of abiotic environmental factors in structuring the functional composition of chironomid assemblages in streams. However, analysing the functional composition of assemblages provides precious information about the ecological condition of, and processes in, streams. A trait-based approach could link the biological patterns and processes, and it is independent of the geographical distance between assemblages (Verberk et al. 2008). Patterns in species traits are significantly related to differences in the environmental conditions where the species occur, thus habitats act as a template for species traits (e.g. Statzner et al. 1994, Southwood 1977, Townsend et al. 1997).

Consequently, our study focuses on the variability of taxonomic and functional composition of chironomid assemblages in a small mountain range. We assumed highly variable abiotic condition of habitats in second-order headwater streams located within one mountain range, but consisting of two different catchment areas characterized by different bedrock types. We hypothesised differences between the sites in taxonomic composition but not in functional composition. Our aim was to assess the factors influencing the hierarchical nested spatial scale structuring the taxonomic and functional compositions of chironomid assemblages. 


\section{Material and methods}

\section{Study area}

The survey area is located in the Mecsek Mountains, which is one of the most southern mountain ranges in the Carpathian Basin (Fig. 1). It is considerably isolated from other mountain regions and surrounded by plains and low hilly territories. This relatively small $\left(350 \mathrm{~km}^{2}\right)$, geologically and climatically heterogeneous area is located in a biogeographic transition zone (Praeillyricum) between the Pannonian and the Mediterranean (Dinaric, Illyrian, Moesian) ecoregions (Borhidi 2003, Borhidi 2006). The major part of the area is covered by Jurassic-and Cretaceous-aged bedrocks of limestone and different volcanic sediments, whereas red and grey sandstones are dominant in the western region (Gebhardt 1967).

\section{Data collection}

Chironomidae larvae samples were taken from second-order streams running in deep, cool and shaded valleys. We chose 3 near-pristine streams from the south-western region and 3 from the north-eastern region that could be characterized by different geological features and belong to two different catchment areas (Fig. 1).

Each site was sampled three times in 2009 (May, July and October) and once in 2010 (March). Samples were quantitatively collected according to the Integrated Assessment System

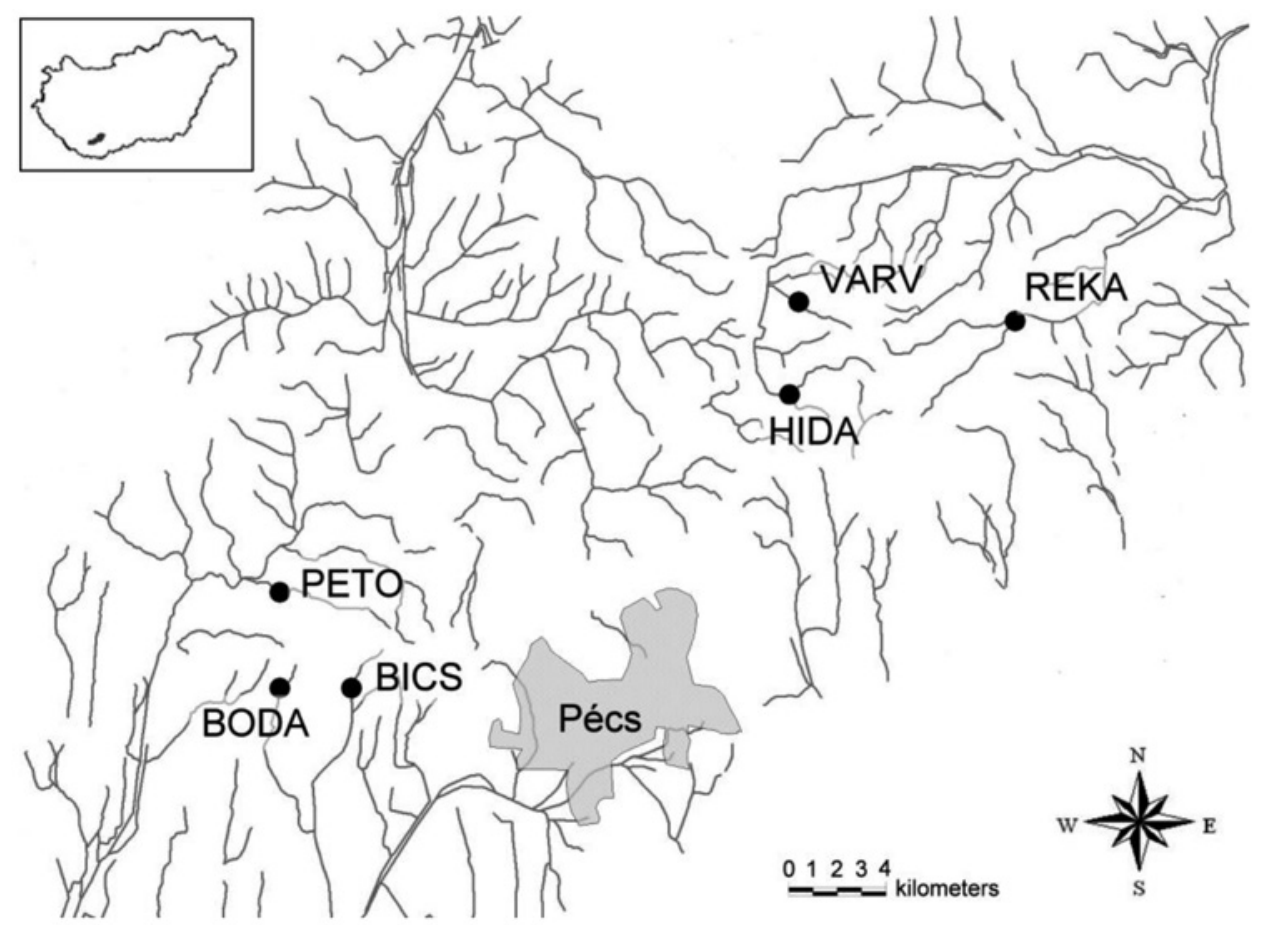

Fig. 1. Schematic outline of the water system and study sites in the Mecsek Mountains. Sites characterized by sandstone bedrock:

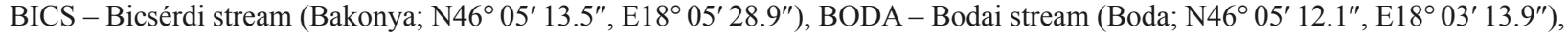
PETO - Petőczi stream (Bakonya; N46 07' 16.6", E18 03' 42.2"); sites characterized by limestone bedrock: HIDA - Hidasi valley

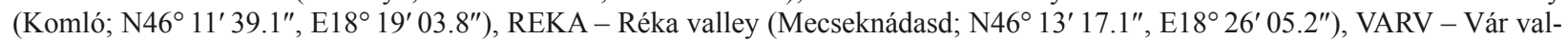
ley at Máré spring (Magyaregregy; N46 13' 40.0"; E18 19' 19.4").

Table 1. List of microhabitat types based on the AQEM protocol (AQEM Consortium 2002) and the cumulative microhabitat groups.

\begin{tabular}{lll}
\hline Groups & Type & Definition \\
\hline Sand, silt & Argyllal & Silt, loam, clay; diameter $<6 \mu \mathrm{m}$ \\
& Psammal & Sand; diameter $6 \mu \mathrm{m}-2 \mathrm{~mm}$ \\
Akal & Akal & Fine to medium-sized gravel; diameter $2 \mathrm{~mm}-2 \mathrm{~cm}$ \\
Lithal & Microlithal & Coarse gravel with medium to fine gravel; diameter $2-6 \mathrm{~cm}$ \\
& Mesolithal & Cobbles with a variable percentage of gravel and sand; diameter $6-20 \mathrm{~cm}$ \\
& Macrolithal & Coarse cobbles, gravel and sand; diameter $20-40 \mathrm{~cm}$ \\
Biotic & Xylal & Tree trunks, dead wood, branches, roots \\
& CPOM & Deposits of coarse particulate organic matter \\
& FPOM & Deposits of fine particulate organic matter \\
\hline
\end{tabular}


Table 2. Mean (standard deviation) values of local environmental variables and their type of transformation for ADONIS. $p$-values indicate statistical significance based on independent $t$ - test: $* * * p<0.001 ; * * p<0.01 ; * p<0.05$, ns $=$ non-significant $(p>0.05)$; na $=$ no results, because of the zero variance.

\begin{tabular}{|c|c|c|c|c|}
\hline Variables & Sandstone & Limestone & Transf. & $p$ \\
\hline \multicolumn{5}{|l|}{ Streambed morphology } \\
\hline \multicolumn{5}{|l|}{$\%$ proportion of microhabitat types: } \\
\hline$\%$ Macrolithal & $0.27(0.52)$ & $0.98(1.53)$ & $\arcsin (\mathrm{x} / 100)^{0.5}$ & ns \\
\hline$\%$ Mesolithal & $18.63(15.13)$ & $45.46(15.07)$ & $\arcsin (\mathrm{x} / 100)^{0.5}$ & $* * *$ \\
\hline$\%$ Microlithal & $18.87(13.24)$ & $13.056(9.54)$ & $\arcsin (\mathrm{x} / 100)^{0.5}$ & $\mathrm{~ns}$ \\
\hline$\%$ Akal & $17.51(14.6)$ & $13.35(11.16)$ & $\arcsin (\mathrm{x} / 100)^{0.5}$ & ns \\
\hline$\%$ Psammal & $28.25(15.87)$ & $15.25(12.05)$ & $\arcsin (\mathrm{x} / 100)^{0.5}$ & ns \\
\hline$\%$ Argyllal & $14.14(14.97)$ & $8.55(6.21)$ & $\arcsin (\mathrm{x} / 100)^{0.5}$ & ns \\
\hline$\%$ Xylal & $4.21(4.15)$ & $4.63(3.96)$ & $\arcsin (\mathrm{x} / 100)^{0.5}$ & $\mathrm{~ns}$ \\
\hline$\%$ CPOM & $9.18(9.75)$ & $12.14(10.45)$ & $\arcsin (\mathrm{x} / 100)^{0.5}$ & $\mathrm{~ns}$ \\
\hline$\%$ FPOM & $1.8(3.72)$ & $0(0)$ & $\arcsin (\mathrm{x} / 100)^{0.5}$ & na \\
\hline$\%$ frequency of detritus (FPOM, CPOM) in $100 \mathrm{~m}$ & $28.15(14.53)$ & $31.08(11.96)$ & $\arcsin (\mathrm{x} / 100)^{0.5}$ & ns \\
\hline$\%$ frequency of washaway in $100 \mathrm{~m}$ & $19.84(13.25)$ & $15.45(6.86)$ & $\arcsin (\mathrm{x} / 100)^{0.5}$ & ns \\
\hline Number of riffles in $100 \mathrm{~m}$ & $4.67(3.65)$ & $5(1.76)$ & $\ln (\mathrm{x}+1)$ & ns \\
\hline Number of pools in $100 \mathrm{~m}$ & $2.92(2.43)$ & $4.33(1.92)$ & $\ln (x+1)$ & ns \\
\hline Number of woods in $100 \mathrm{~m}$ & $6.58(3.15)$ & $12.5(5.55)$ & $\ln (x+1)$ & ns \\
\hline Number of bends in $100 \mathrm{~m}$ & $4.17(2.25)$ & $3.67(1.15)$ & $\ln (x+1)$ & ns \\
\hline Average channel width (m) & $1.42(0.56)$ & $2.56(0.59)$ & $\ln (x+1)$ & $* * *$ \\
\hline Average water depth (m) & $0.09(0.09)$ & $0.08(0.03)$ & $\ln (x+1)$ & ns \\
\hline \multicolumn{5}{|l|}{ Physicochemical features } \\
\hline Water temperature $\left({ }^{\circ} \mathrm{C}\right)$ & $13.28(3.32)$ & $12.4(4.38)$ & $\ln (x+1)$ & ns \\
\hline $\mathrm{pH}$ & $8.34(0.25)$ & $8.31(0.31)$ & $\exp (\mathrm{x} / 100)$ & ns \\
\hline Conductivity $(\mu \mathrm{S} / \mathrm{cm})$ & $856.25(162.68)$ & $537.13(24.27)$ & $\exp (\mathrm{x}) / 100$ & $* * *$ \\
\hline dissolved $\mathrm{O}_{2}\left(\mathrm{mg} \mathrm{l}^{-1}\right)$ & $7.52(2.21)$ & $7.98(1.66)$ & $\ln (x+1)$ & ns \\
\hline $\mathrm{SO}_{4}^{2-}\left(\mathrm{mg} \mathrm{l}^{-1}\right)$ & $98.57(128.62)$ & $32.12(21.67)$ & $\ln (x+1)$ & ns \\
\hline $\mathrm{Ca}^{2+}\left(\mathrm{mg} \mathrm{l}^{-1}\right)$ & $117.03(36.47)$ & $93.12(10.64)$ & $\ln (x+1)$ & ns \\
\hline $\operatorname{Mg}^{2+}\left(\mathrm{mg} \mathrm{l}^{-1}\right)$ & $62.55(44.41)$ & $16.33(6.39)$ & $\ln (x+1)$ & $* *$ \\
\hline $\mathrm{Cl}^{-}$ & $10.76(4.43)$ & $3.03(0.54)$ & $\ln (x+1)$ & $* * *$ \\
\hline $\mathrm{HCO}_{3}^{-}$ & $428.03(103.7)$ & $304.28(62.86)$ & $\ln (x+1)$ & $* *$ \\
\hline $\mathrm{m}$ alkalinity & $7.19(1.41)$ & $5.28(0.82)$ & $\ln (x+1)$ & $* * *$ \\
\hline \multicolumn{5}{|l|}{ Riparian vegetation } \\
\hline$\%$ Tree $(0-1 \mathrm{~m})$ & $12.16(8.66)$ & $16.56(8.03)$ & $\arcsin (\mathrm{x} / 100)^{0.5}$ & ns \\
\hline$\%$ shrubs $(0-1 \mathrm{~m})$ & $11.93(7.67)$ & $6.58(5.8)$ & $\arcsin (\mathrm{x} / 100)^{0.5}$ & $*$ \\
\hline$\%$ herbaceous $(0-1 \mathrm{~m})$ & $61.87(18.44)$ & $46.66(14.42)$ & $\arcsin (x / 100)^{0.5}$ & $*$ \\
\hline META naturalness index at the valley floor & $3.53(0.15)$ & $3.87(0.15)$ & $\ln (x+1)$ & $* * *$ \\
\hline$\%$ Forest coverage at the valley floor & $93.33(9.85)$ & $98.33(2.46)$ & $\arcsin (\mathrm{x} / 100)^{0.5}$ & $\mathrm{~ns}$ \\
\hline$\%$ of natural habitats of vegetation at valley floor & $50(0)$ & $66.7(0)$ & $\arcsin (\mathrm{x} / 100)^{0.5}$ & na \\
\hline META naturalness index at the nearest slopes & $3.5(0.43)$ & $3.82(0.3)$ & $\ln (x+1)$ & $*$ \\
\hline$\%$ Forest coverage at the nearest slopes & $83.33(17.75)$ & $100(0)$ & $\arcsin (\mathrm{x} / 100)^{0.5}$ & $* *$ \\
\hline$\%$ of natural habitats of vegetation at slope & $44.4(43.4)$ & $100(0)$ & $\arcsin (\mathrm{x} / 100)^{0.5}$ & na \\
\hline \multicolumn{5}{|l|}{ Climate } \\
\hline Annual mean temperature $\left({ }^{\circ} \mathrm{C}\right)$ & $10.7(0.26)$ & $9.97(0.06)$ & $\ln (\mathrm{x}+1)$ & $* *$ \\
\hline Mean diurnal range & $9.17(0.06)$ & $8.97(0.06)$ & $\ln (\mathrm{x}+1)$ & $*$ \\
\hline Temperature seasonality & $773.27(5.54)$ & $768.3(1.57)$ & $\ln (x+1)$ & ns \\
\hline Max temperature of warmest month $\left({ }^{\circ} \mathrm{C}\right)$ & $26.8(0.35)$ & $25.87(0.06)$ & $\ln (\mathrm{x}+1)$ & $*$ \\
\hline Min temperature of coldest month $\left({ }^{\circ} \mathrm{C}\right)$ & $-4.27(0.15)$ & $-4.67(0.06)$ & $\ln (x+1)$ & $*$ \\
\hline Temperature annual range & $31.07(0.21)$ & $30.53(0.06)$ & $\ln (x+1)$ & $*$ \\
\hline Mean temp. of wettest quarter $\left({ }^{\circ} \mathrm{C}\right)$ & $18.57(0.29)$ & $17.87(0.06)$ & $\ln (x+1)$ & $*$ \\
\hline Mean temperature of driest quarter $\left({ }^{\circ} \mathrm{C}\right)$ & $1.93(0.15)$ & $1.2(0)$ & $\ln (\mathrm{x}+1)$ & na \\
\hline Mean temperature of warmest quarter $\left({ }^{\circ} \mathrm{C}\right)$ & $20.07(0.29)$ & $19.37(0.06)$ & $\ln (x+1)$ & $*$ \\
\hline Mean temperature of coldest quarter $\left({ }^{\circ} \mathrm{C}\right)$ & $0.13(0.15)$ & $-0.43(0.06)$ & $\ln (x+1)$ & $*$ \\
\hline Annual precipitation (mm) & $669.67(10.12)$ & $664.33(8.02)$ & $\ln (x+1)$ & ns \\
\hline Precipitation of wettest month (mm) & $89.67(2.31)$ & $90.67(1.53)$ & $\ln (x+1)$ & ns \\
\hline
\end{tabular}


Table 2. Continued.

\begin{tabular}{|c|c|c|c|c|}
\hline Variables & Sandstone & Limestone & Transf. & $p$ \\
\hline Precipitation of driest month $(\mathrm{mm})$ & $37.67(0.58)$ & $35.33(0.58)$ & $\ln (x+1)$ & $* *$ \\
\hline Precipitation seasonality & $26.67(0.58)$ & $26.67(0.58)$ & $\ln (x+1)$ & ns \\
\hline Precipitation of wettest quarter (mm) & $224(5.2)$ & $223.67(3.51)$ & $\ln (x+1)$ & ns \\
\hline Precipitation of driest quarter (mm) & $117(1.73)$ & $120.33(1.53)$ & $\ln (x+1)$ & ns \\
\hline Precipitation of warmest quarter $(\mathrm{mm})$ & $221.33(4.62)$ & $220(3.61)$ & $\ln (x+1)$ & ns \\
\hline Precipitation of coldest quarter $(\mathrm{mm})$ & $131(1.73)$ & $133.33(1.53)$ & $\ln (x+1)$ & ns \\
\hline \multicolumn{5}{|l|}{ Hydrology } \\
\hline Distance from source $(\mathrm{km})$ & $2.8(1.17)$ & $3.93(0.79)$ & $\ln (\mathrm{x}+1)$ & ns \\
\hline Altitude (m) & $213.67(37.61)$ & $331.33(14.5)$ & $\ln (x+1)$ & $*$ \\
\hline Aspect & $215.74(92.87)$ & $131.79(59.77)$ & $\ln (x+1)$ & ns \\
\hline Slope $(\%)$ & $6(1)$ & $5.3(1.5)$ & $\ln (x+1)$ & $\mathrm{ns}$ \\
\hline
\end{tabular}

for the Ecological Quality of Streams and Rivers throughout Europe using Benthic Macroinvertebrates (AQEM) (AQEM Consortium 2002), which focuses on a multihabitat scheme designed for sampling major habitats in proportion to their presence within $100 \mathrm{~m}$ long sampling reaches. Nine microhabitat types were determined (Table 1) based on the original AQEM microhabitats. After collection, each sampling unit was fully and accurately sorted into sampling bottles in the field keeping the samples separate from each other. For appropriate identification, the specimens were slide-mounted in Euparal. The chironomid larvae were identified using keys and descriptions of Cranston (1982), Wiederholm (1983), Janecek (1998), Sæther et al. (2000) and Vallenduuk \& Moller Pillot (2007). The nomenclature follows Sæther \& Spies (2011).

\section{Environmental variables}

At each site, 36 local scale environmental variables were taken in all seasons related to streambed morphology (17), physicochemical attribute (10) and riparian vegetation (9) (Table 2). Water samples for physicochemical analyses were taken prior to the biological sampling. We calculated indices of naturalness of riparian vegetation and vegetation of the nearest slopes based on the Landscape Ecological Vegetation Database and Map of Hungary (Molnár et al. 2007, Molnár \& Horváth 2008).

Furthermore, we obtained the microclimatic condition of sampling sites from the WorldClim-Global Climate Data website (www.worldclim.org, Hijmans et al. 2005). At first, layers of the latest 30 years' mean climatic parameters related to the temperature and the precipitation were downloaded, and then projected the locality coordinates to these layers. Finally, we gained the values of 18 selected climatic parameters for each site (Table 2). Hydrological parameters (slope, aspect, altitude) were also determined from WorldClim-Global Climate Data website. For these procedures we used software R ver. 2.14.0 (R Development Core team 2011) using the packages 'rgdal' and 'dismo'. The longitudinal position of sites was obtained by measuring the streamline distance of the sites from source using Geographical Information System (GIS).

Due to sampling procedures, the local scale environmental parameters were measured seasonally. While seasonal information about the microclimate and hydrological parameters was not available, these were derived from the monthly data (Hijmans et al. 2005). Despite weaker comparability, we kept the seasonal data of local scale environmental variables to increase the reliability of statistical analysis.

\section{Species traits}

We considered three main traits to characterize the functional composition of chironomid assemblages: (1) saprobic preference, (2) stream zonation preference, and (3) functional feeding groups (Table 4). These traits are highly influential for functional organisation of freshwater macroinvertebrate assemblages (Moog 2002). The categories of traits and the basic autecological information of species were provided according to Moog (2002), Schmedtje \& Colling (1996), and the information collected by AQEM consortium (Brabec et al. 2007). We calculated the percentage proportion of trait categories at each sample using Asterics ver. 3.3.1 software (AQEM Consortium 2002). For all analyses, the three main traits were handled separately, since each one characterizes different ecological attributes of streams (Moog 2002).

\section{Data analysis}

Prior to all analysis, we removed the extremely rare taxa $(<0.2 \%$ relative abundance) from the dataset to reduce their disproportionate effect in the multivariate analysis (Legendre $\&$ Legendre 1998). The assemblage dataset was $\log 10(\mathrm{x}+1)$ transformed.

To evaluate the differences in the abiotic habitat conditions between two catchments and four sampling times, we conducted permutational multivariate analyses of variance using distance matrices (ADONIS; 9999 runs, Euclidean distance measure) (Oksanen 2011). We used sampling occasions (6 sites $\times 4$ times) as objects, environmental parameters as response variables, and catchment (2 levels) and sampling time (4 levels) as grouping variables within one model. We excluded the interaction of two grouping variables from our models. We handled the five environmental variable groups (streambed morphology, physicochemical attributes, riparian vegetation, microclimate and hydrology) separately. Before the analyses, the environmental variables were transformed depending on their scale of measurement to reach their normality and reduce heteroscedasticity (see Table 2). We also used independent t-tests to determine the significantly different $(\alpha=0.05)$ environmental variables between catchments having distinct bedrock type. Finally, we tested the significantly different abiotic variables for autocorrelation using Spearman rank-correlation.

We examined the differences of taxonomic and functional composition between sites and catchments using Discriminant Analysis of Principal Components (DAPC). This method was 
originally developed to identify and describe genetic clusters, although it can be applied to any quantitative data (Jombart et al. 2010). This multivariate approach gains the principal components of raw data using Principal Component Analysis (PCA) as a prior step to Discriminant Analysis (DA). Then during DA, linear combinations of the retained principal components called discriminant functions are constructed, which provide the best separation between the groups. The coefficients of the original variables used in DA quantify their relative contributions to the discriminant functions. The value of relative contribution could vary between 0 and 1 , where 1 means the summarized contribution of the original variables to the distinct discriminant function. Moreover, being based on the DA, the cross-validation procedure within DAPC provides membership probabilities of each object for the different groups based on the retained discriminant functions. The advantage of this method over other indirect ordination methods (e.g. PCA, CA, DA) is that it ensures that variables submitted to DA are perfectly uncorrelated and their number is less than the number of the analysed objects. Other ordination methods (e.g. PCA, CA, DA) are sensitive for these latter settings (further details in Jombart et al. 2010). Without implying a necessary loss of information, this transformation allows DA to be applied to any ecological dataset, which suffer from large amounts of highly correlated variables, but low numbers of objects. In our case, less variables existed than objects (e.g. saprobic categories, feeding categories), but these were highly correlated. Furthermore, in contrast to other non-linear ordination or clustering techniques (e.g. NMDS) the DAPC provides information not only about the differences or similarities between the objects but also those variables that cause the separation of objects. We used four input matrixes in our settings. Abundance data of species and the relative frequencies of traits were used as variables, and the sampling occasions (sampling site $\times$ sampling time) were used as objects. We applied six a priori groups according to sampling sites. Centroids of these groups, as a mean of $\mathrm{x}$ and $\mathrm{y}$ coordinates of objects (sampling occasions) belonging to the same group (sampling site), were calculated and marked on our ordination plots. To clarify the meanings of discriminant functions within DAPC, Pearson correlations were calculated between the discriminant axes and the original variables.

ADONIS was also used to test for differences in chironomid assemblages in a nested hierarchical design accounting for 1) microhabitats 2) within streams 3) within catchments and separate sampling times (see also Garcia-Rogers et al. 2011). A total of 9999 runs were performed on Bray-Curtis distance matrix for the taxonomic dataset and Gower distance matrix for the functional datasets. For these analyses, we contracted the nine microhabitat types into four wider habitat groups (Table 1). We separated Akal from other lithal microhabitat types. Presumably, it has different chironomid assemblages because the small grain sized Akal microhabitat could not provide shelters against water-current for bigger chironomid species. We cumulated the abundance of each species and standardized them to $1 \mathrm{~m}^{2}$, because different numbers of sampling units of single microhabitat types were available in each sampling site.

All statistical analyses were performed with software $\mathrm{R}$ ver. 2.14.0 (R Development Core team 2011) using the packages 'vegan' for ADONIS and 'adegenet' for DAPC.

\section{Results}

\section{Abiotic habitat characterization}

Using ADONIS, three out of five environmental variable groups showed significant differences $(\alpha=0.05)$ between two groups of sites having distinct bedrock type and belong to two different catchments (Table 3 ). The influence of catchments was more effective in differentiation of samples regarding their riparian vegetation (39\% significantly explained variance), microclimate ( $87 \%$ explained variance) and hydrology ( $33 \%$ explained variance) than in differentiation of samples regarding their physicochemical features (15\% significantly explained variance) and streambed morphology ( $11 \%$ significantly explained variance). The seasonal effect was statistically significant only in the case of physicochemical characteristics $(74 \%$ explained variance). Analysing the environmental variables separately using independent t-tests, two variables within streambed morphology, five within physicochemical feature of water, five within riparian vegetation, nine within microclimate and one within hydrology were significantly different between catchments having distinct bedrock types (Table 2). Among the significantly different physicochemical variables, 5 pairs (conductivity $-\mathrm{Mg}^{2+}, \mathrm{Cl}^{-}, \mathrm{HCO}_{3}^{-}$, m alkalinity; $\mathrm{HCO}_{3}{ }^{-} \mathrm{m}$ alkalinity) highly correlated (Spearman

Table 3. Results of ADONIS assessing the effect of spatial and temporal variability on abiotic habitat conditions. The different types of environmental variables were analysed separately.

\begin{tabular}{lrrrc}
\hline Source of variation & df & F & $\mathbf{R}^{\mathbf{2}}$ & $\boldsymbol{p}$ \\
\hline Streambed morphology & & & & \\
Catchment & 1 & 2.818 & 0.11 & 0.038 \\
Season & 3 & 0.899 & 0.11 & 0.529 \\
Residuals & 19 & & 0.77 & \\
Physicochemical feature & & & & \\
Catchment & 1 & 24.847 & 0.15 & 0.000 \\
Season & 3 & 41.563 & 0.74 & 0.000 \\
Residuals & 19 & & 0.11 & \\
Riparian vegetation & & & & \\
Catchment & 1 & 12.499 & 0.39 & 0.000 \\
Season & 3 & 0.118 & 0.01 & 0.997 \\
Residuals & 19 & & 0.59 & \\
Microclimatic condition & & & & \\
Catchment & 1 & 25.923 & 0.87 & 0.101 \\
Residuals & 4 & & 0.13 & \\
Hydrology & & & & \\
Catchment & 1 & 1.935 & 0.33 & 0.192 \\
Residuals & 4 & & 0.67 & \\
\hline
\end{tabular}


$r>0.7)$ with each other. Among the significantly different climate parameters, only 1 pair (annual range of temperature - precipitation of driest month) did not show high correlation (Spearman $r>0.7$ ) with each other. We did not find strongly correlated variable pairs among significantly different streambed and riparian vegetation characteristics.

\section{Variability of taxonomic and functional composition}

A total of 715 specimens belonging to 36 taxa (24 genera and 5 subfamilies) were found at 6 sites during our one-year investigation. Five taxa were specific in sites situated in limestone bedrock, 23 in sandstone and only 6 were common on both bedrock types (Appendix 1$)$. Eleven taxa were extremely rare $(<0.2 \%$ relative abundance), thus we omitted these from further analyses. We did not find any chironomid individuals in Réka valley during autumn.

DAPC revealed that four sampling sites (BICS, BODA, PETO, REKA) form separate groups along the first two discriminant functions (Fig. 2A). Slight separation and frequent overlapping can be seen between our a priori groups (sampling sites) on the ordination diagrams of functional compositions (Fig. 2B,
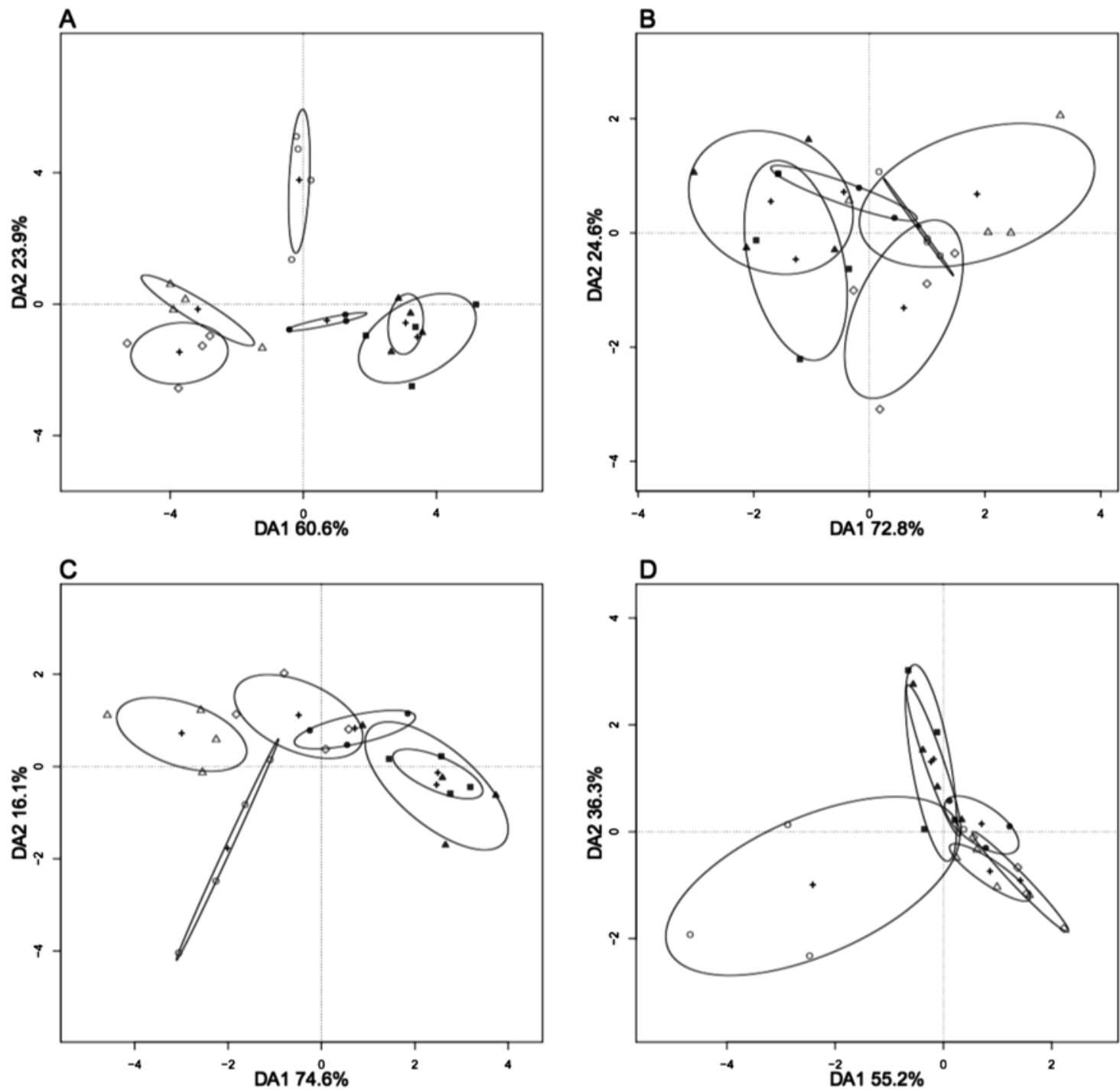

Fig. 2. Using DAPC, differences could be shown in (A) taxonomic and in functional composition: (B) saprobic preference, (C) stream zonation preference, (D) the distribution of functional feeding groups of chironomid assemblages between headwaters belonging to different catchments. Sampling sites were plotted on the ordination diagram. Different symbols mean the sampling occasions at the different sites: $\odot-$ BICS, $\triangle$ - BODA, $\diamond-$ PETO, $\mathbf{-}-$ HIDA, $\bullet-$ REKA, $\Delta-$ VARV. Sites situated on sandstone bedrock are marked with empty symbols; sites on limestone are marked with fulfilled symbols. The centroids of sites were marked with ' + ' and $1.5 *$ standard deviation are drawn around the centroids. 
Table 4. Relative contribution (rel. contr.) of original variables to the variability of the first two axes of DAPC (DA1, DA2) and Pearson correlation $(r)$ between original variables and the first two discriminant axes. P-values indicate statistical significance based on Pearson correlation: ${ }^{* *} p<0.001 ; * * p<0.01 ; * p<0.05$. The full names of taxa are listed in Appendix 1 .

\begin{tabular}{|c|c|c|c|c|c|c|c|c|c|}
\hline \multirow[t]{2}{*}{ Taxa } & \multicolumn{2}{|c|}{ rel. contr. } & \multicolumn{2}{|c|}{ Pearson $r$} & \multirow[t]{2}{*}{ Functional groups } & \multicolumn{2}{|c|}{ rel. contr. } & \multicolumn{2}{|c|}{ Pearson $\mathrm{r}$} \\
\hline & DA1 & DA2 & DA1 & DA2 & & DA1 & DA2 & DA1 & DA2 \\
\hline A_tri & 0.02 & 0.02 & -0.40 & 0.03 & Saprobic preferences & & & & \\
\hline B_bif & 0.01 & 0.15 & -0.11 & $0.85 * * *$ & xenosaprob & 0.01 & 0.09 & $0.67 * * *$ & 0.35 \\
\hline Con_sp & 0.01 & 0.02 & $-0.43 *$ & 0.39 & oligosaprob & 0.20 & 0.00 & 0.31 & $0.66 * * *$ \\
\hline D_cin & 0.00 & 0.01 & -0.01 & $0.58 * *$ & $\beta$-mesosaprob & 0.68 & 0.01 & $-0.87 * * *$ & 0.29 \\
\hline E_eph & 0.11 & 0.01 & 0.36 & -0.26 & $\alpha$-mesosaprob & 0.00 & 0.01 & -0.68 & -0.29 \\
\hline Ma_sp & 0.04 & 0.11 & -0.26 & 0.14 & polysabrop & 0.11 & 0.90 & 0.05 & $-0.75 * * *$ \\
\hline Mi_not & 0.02 & 0.01 & $-0.53 * *$ & 0.27 & Stream zonation pref & & & & \\
\hline Mi_chl & 0.03 & 0.08 & 0.10 & $-0.46^{*}$ & crenal & 0.11 & 0.13 & $-0.76 * * *$ & $-0.56 * *$ \\
\hline Mi_ped & 0.06 & 0.01 & -0.21 & -0.31 & hcrenal & 0.03 & 0.01 & $-0.62 * *$ & $-0.43 *$ \\
\hline Nat_sp & 0.19 & 0.00 & $-0.60 * *$ & -0.30 & epirithral & 0.02 & 0.00 & -0.26 & 0.00 \\
\hline O_ful & 0.02 & 0.00 & -0.11 & 0.36 & metarithral & 0.04 & 0.03 & 0.09 & -0.08 \\
\hline Ort_sp & 0.01 & 0.00 & -0.17 & $0.43 *$ & hyporithral & 0.14 & 0.17 & $0.54 * *$ & -0.19 \\
\hline Ort_thi & 0.00 & 0.02 & 0.10 & $0.63 * * *$ & epipotamal & 0.01 & 0.05 & 0.37 & 0.12 \\
\hline P_sty & 0.02 & 0.07 & -0.12 & $0.61 * * *$ & metapotamal & 0.40 & 0.43 & 0.41 & 0.17 \\
\hline P_ski & 0.01 & 0.02 & 0.10 & 0.26 & hypopotamal & 0.12 & 0.11 & $0.42 *$ & 0.10 \\
\hline$P_{-}$exc & 0.01 & 0.10 & -0.01 & $0.86 * * *$ & littoral & 0.06 & 0.04 & $0.49 *$ & -0.02 \\
\hline $\mathrm{P}_{-}$con & 0.06 & 0.14 & -0.16 & -0.27 & profundal & 0.07 & 0.04 & 0.24 & -0.05 \\
\hline$P \_$ped & 0.06 & 0.04 & -0.34 & -0.28 & Functional feeding gr & oups & & & \\
\hline P_sca & 0.00 & 0.04 & 0.06 & -0.34 & grazers & 0.01 & 0.03 & 0.04 & 0.27 \\
\hline Pro_oli & 0.00 & 0.02 & -0.28 & 0.20 & shredders & 0.69 & 0.29 & $-0.83 * * *$ & $-0.48^{*}$ \\
\hline Rc_fus & 0.01 & 0.02 & -0.15 & -0.24 & collectors & 0.07 & 0.07 & 0.03 & -0.2 \\
\hline Rc_atr & 0.00 & 0.01 & -0.02 & $0.55 * * *$ & active filter feeders & 0.06 & 0.02 & 0.32 & 0.10 \\
\hline Rp_sp & 0.03 & 0.01 & -0.36 & -0.18 & passive filter feeders & 0.00 & 0.39 & -0.09 & $0.51 *$ \\
\hline Rt_sp & 0.27 & 0.06 & $0.47 *$ & -0.05 & predators & 0.15 & 0.18 & 0.39 & $-0.61 * *$ \\
\hline Zav_sp & 0.01 & 0.02 & -0.36 & -0.05 & parasites & 0.03 & 0.02 & 0.00 & $0.52 *$ \\
\hline
\end{tabular}

C, D). The first two discriminant functions explained more than $80 \%$ and the first one explained more than $50 \%$ of total variance in each analysis. Assessing the dataset of taxonomic composition globally, $83 \%$ of objects were grouped correctly in multidimensional space based on cross-validation procedure within DAPC, while this value reached only $61 \%$ in the case of saprobic preference, $65 \%$ in the case of stream zonation preference and $57 \%$ in the case of functional feeding groups.

Seven (Brillia bifida, Epoicocladius ephemerae, Macropelopia sp., Natarsia sp., Paratrissocladius excerptus, Polypedilum convictum, Rheotanytarsus sp.) out of 25 taxa exceeded 0.1 relative contributions to the first two discriminant functions, which explained the separation of our a priori groups (sampling sites) (Table 4). Two groups of sites (located on sandstone and limestone bedrock) separated from each other along the discriminant function 1 , defined by low abundance of Natarsia sp. and high abundance of Rheotanytarsus sp. (Table 4, Figure 2A). On the other hand, Brillia bifida and Paratrissocladius excerptus positively cor- related with and highly contributed to the discriminant function 2, which explained the segregation of BICS from the other sites (Table 4, Fig. 2A).

Analysing the saprobic preference dataset by DAPC, the sampling sites having different bedrock types form separate groups along the discriminant functions 1 (Fig. 2B), defined by high ratio of xenosaprobic, oligosaprobic preference and low ratio of beta-mesosaprobic preference (Table 4). The beta-mesosaprobic preferences were more frequent on limestone bedrock than on sandstone bedrock, where the high ratios of xenosaprobic and oligosaprobic preferences were typical. Sampling sites were sorted according to longitudinal gradient from eucrenal, hypocrenal to hyporithral and hypopotamal sections based on the analysis of stream zonation preference of chironomid assemblages (Fig. 2C). Sampling sites situated on sandstone bedrock were located at the upper end, whereas sampling sites having limestone bedrock could be found at the lower end of this longitudinal gradient (Fig. 2C). Sites having limestone and sandstone bedrocks showed slight differentiation 
Table 5. Summary of the nested ADONIS analyses performed on the taxonomic and functional compositions of chironomid assemblages. The different elements of functional composition were analysed separately.

\begin{tabular}{lrrrc}
\hline Source of variation & df & F & $\mathbf{R}^{2}$ & $\boldsymbol{p}$ \\
\hline Taxonomic composition & & & & \\
Catchment & 1 & 5.282 & 0.07 & 0.00 \\
Stream (catchment) & 4 & 2.081 & 0.11 & 0.00 \\
Microhabitat [stream (catchment)] & 16 & 1.218 & 0.26 & 0.03 \\
Season & 3 & 2.271 & 0.09 & 0.00 \\
Residuals & 36 & & 0.47 & \\
Saprobic preferences & & & & \\
Catchment & 1 & 16.741 & 0.15 & 0.00 \\
Stream (catchment) & 4 & 8.114 & 0.29 & 0.00 \\
Microhabitat [stream (catchment)] & 15 & 1.763 & 0.24 & 0.06 \\
Season & 3 & 3.172 & 0.09 & 0.02 \\
Residuals & 25 & & 0.23 & \\
Stream zonation preferences & & & & \\
Catchment & 1 & 7.989 & 0.10 & 0.00 \\
Stream (catchment) & 4 & 2.566 & 0.13 & 0.02 \\
Microhabitat [stream (catchment)] & 15 & 2.014 & 0.39 & 0.01 \\
Season & 3 & 0.998 & 0.04 & 0.44 \\
Residuals & 26 & & 0.34 & \\
Functional feeding groups & & & & \\
Catchment & 1 & 5.034 & 0.08 & 0.00 \\
Stream (catchment) & 4 & 1.515 & 0.09 & 0.13 \\
Microhabitat [stream (catchment)] & 16 & 0.974 & 0.24 & 0.52 \\
Season & 3 & 1.927 & 0.09 & 0.05 \\
Residuals & 33 & & 0.50 & \\
\hline & & & &
\end{tabular}

along the discriminant function 2 based on functional feeding groups (Fig. 2D), defined by high ratios of passive filter feeders and low ratios of shredders and predators (Table 4). High temporal variability could be found within several sampling sites (e.g. BICS, VARV, HIDA) caused by varying abundance of shredders and passive filter feeders.

Table 5 shows the summary of the numerous spatially nested (catchment, stream, microhabitat) effects on taxonomic and functional composition analysed by ADONIS. The four models explained $50-77 \%$ of total variance in the datasets of chironomid taxonomic and functional compositions. Taxonomic composition, saprobic preference and stream zonation preference were significantly $(\alpha=0.05)$ affected by all of the spatially nested factors, whereas only the catchment level showed significant effects on the frequencies of functional feeding groups. The effects of sampling time were statistically significant $(\alpha=0.05)$ except for stream zonation. Microhabitat level (microhabitat within streams within catchment) explained the highest percentage of variance in the datasets of taxonomic composition $(26 \%)$ and stream zonation preference $(39 \%)$. The influence of stream level was the most important in structuring the composition of saprobic preference $(29 \%)$ and the season $(9 \%)$ for functional feeding groups.

\section{Discussion}

We showed that spatial changes in taxonomic and functional composition of midges accompanied by changes in habitat features mainly in chemical characteristics related to geology, riparian vegetation, microclimate and altitude. Fine-scale physical structure (i.e. microhabitat scale) played a major role not only in organizing taxonomic composition, but also the functional composition of chironomid assemblages. However, our results should be interpreted with some caution because of the small sample size.

\section{Spatial variability in habitat features}

Two habitat types could be distinguished, which were characterized not only by different geological features, but also inorganic chemical characteristics, riparian vegetation, microclimate and altitude (Tables 2 and 3). Sites located at the south-western area of the Mecsek Mts. and having sandstone bedrock could be characterized by higher concentrations of inorganic ions, higher proportions of washaway and herbaceous plants in riparian vegetation, higher annual ranges of temperature, higher air temperatures during the whole year, higher amounts of precipitation in driest month, lower altitudinal positions and smaller channel width than the sites located at the north-eastern part of the mountains having limestone bedrock. These latter sites were surrounded by more natural vegetation than the streams running in sandstone bedrock.

Analysis of abiotic habitat features revealed differences between environmental factors regarding their temporal and spatial variability (Table 3 ). Slight differences in habitat features were found between the streambed morphology of the two catchment areas. Only 2 out of 16 parameters (proportion of mesolithal microhabitat type, channel width) showed significant differences. From the variables used to describe the longitudinal gradient of streams (e.g. channel width, distance from source, altitude, slope) only two (altitude, channel width) showed statistically significant differences between catchments. Similar hydrological and streambed morphological conditions of sites indicated slight differences between longitudinal posi- 
tions of two groups of sites. Only the physicochemical feature of water proved to be significantly different between seasons because of stream flow fluctuations. Due to low numbers of samples (3 samples) within catchments and weak reliability of statistical analysis, our results did not show significant differences between climate conditions of the two catchment areas. However, 9 out of 18 climatic parameters proved to be significantly different. We suspected that microclimatic differences were much more related to the aspect, the direction and the altitude of valley of streams than south-north gradient.

\section{Variability of taxonomic and functional composition}

We found differences not only in taxonomic composition but also in functional composition of chironomid assemblages between headwaters belonging to different catchments. Taxonomic composition $(6$ common out of 36 taxa) differed sharply between the two sides of mountain range within a relatively small spatial distance. This is similar to terrestrial studies on the flora and fauna of Mecsek Mountains and its surroundings. Several studies found strong south-north gradients, which provided evidence for southern colonization processes (e.g. Kevey \& Horvát 1986, Meusel \& Jager 1989). Despite the observed gradient in taxonomic composition of chironomid assemblages, genera found in the Mecsek Mountains are widely distributed in the Palaearctic (Ashe et al. 1987), and species that occur only in the south-western area of mountains do not have south European origins (Sæther \& Spies 2011).

We could not show direct relationships between the variability of chironomid assemblages and local environmental factors, although several previous studies highlighted that the spatial distribution of chironomid larvae is closely related to those abiotic characteristics that were significantly different among two groups of sites in our study (e.g. catchment geology, $\mathrm{pH}$, altitude, local climate) (Calle-Martinez \& Casas 2006, Puntí et al. 2009, Raposeiro et al. 2011, Rosa et al. 2011). Puntí et al. (2009) detected the altitude effect on chironomid assemblages in Mediterranean region, due to its considerable influence on local climate and other physical conditions. Raposeiro et al. (2011) emphasised that local scale physicochemical and hydromorphological factors had an important role in determining the distribution patterns of chironomid assemblages after colonization in Azorean streams. Therefore, we believe that species sorting through local adaptation to altering abiotic conditions played an important role in the separation of chironomid assemblages among catchments compared to geographical and historical effects (e.g. dispersal limitation) within the studied mountain range.

We found moderate but statistically significant separation of functional composition among catchments (Table 4, Fig. 2). In the case of saprobic and stream zonation preference of chironomids, sites were ordered according to an upstream-downstream gradient (Vannote et al. 1980, Moog 2002). Based on the functional preference of midge taxa, sandstone bedrock sites indicated crenal and hypocrenal habitats with low saprobic level, whereas limestone bedrock sites indicated hyporithral and potamal habitats with higher saprobic level. The distribution patterns of functional feeding groups mainly followed the subtle gradient mentioned above corresponding to the predictions of the RCC. However, the observed discrepancies could be explained by stream or catchment specific ecological processes and abiotic characteristics. For example, the ectoparasitic/phoretic (Svensson 1979) Epoicocladius ephemerae was frequent in limestone sites due to the high abundance of its host organism (Ephemera danica) (Szivák et al. 2010, Méhes et al. 2012). At the same sites, the dominance of lithal substrate affected the abundance of grazers and scrapers by providing optimal habitat conditions for periphyton growth (Schneider et al. 2012).

Our results indicated a slight internal shift in functional composition within the second order stream stretches. This gradient seems to be associated with channel width or altitude instead of the distance of the sites from the source. These results are in accordance with Grubbs (2011), who found that subtle downstream functional changes of macroinvertebrate assemblages are typical in forested headwaters.

Spatial variability in taxonomic and functional structure of chironomid assemblages was examined at multiple scales (i.e. from microhabitat to catchment) (Table 4). The most important factor structuring midge assemblages was the microhabitat. Several previous studies (Lencioni \& Rossaro 2005, García-Roger et al. 2011, Rosa et al. 2011) pointed out that the microhabitat type has a finer scale effect in structuring macroinvertebrate assemblage, which could explain an important part of the spatial variation. Furthermore, internal microhabitat heterogeneity had an important role in structuring the functional patterns of chironomid assemblages in our streams. Habitats with different particle sizes and features could have very distinct physical conditions (e. g. current velocity, water depth, temperature) and hence, organic nutrient characteris- 
tics, which presumably caused the co-occurrence of several species characterized by very diverse zonation and saprobic preference within the same reach of streams. Nevertheless other studies confirmed that spatial distribution of functional feeding groups between habitat patches is a mosaic within reaches (e.g. Winemiller et al. 2010). We did not observe this phenomenon (Table 5). In the case of functional feeding groups, the effects of sampling time and catchments proved to be primarily significant. In conclusion, chironomid larval assemblages were influenced by mountain massif even at relatively small spatial scales. We highlighted that the taxonomic and functional composition of chironomid larvae respond strongly to natural environmental gradients similarly to other macroinvertebrate groups (e.g. Heino et al. 2007).

\section{Acknowledgement}

We express our gratitude to three anonymous reviewers and Tibor Erős whose comments contributed to substantially improve this paper. We thank Thomas G. Horvath (SUNY Oneonta, USA) for providing language improvements. We wish to thank Réka Boda, Tamás Zoltán Kovács and Péter Mauchart for their help in the field and in the laboratory.

\section{References}

AQEM Consortium, 2002: Manual for the application of the AQEM method. A comprehensive method to assess European streams using benthic macroinvertebrates, developed for the purpose of the Water Framework Directive. Version 1.0 .

Armitage, P. D., \& Blackburn, J. H., 1985: Chironomidae in a Pennine stream system receiving mine drainage and organic enrichment. - Hydrobiologia 121: 165-172.

Ashe, P., Murray, D. A. \& Reiss, F., 1987: The zoogeographical distribution of Chironomidae (Insecta: Diptera). - Ann. Limnol. 23: 27-60.

Borhidi, A., 2003: Magyarország növénytársulásai. - Akadémiai Kiadó, Budapest. pp. 1-610.

Borhidi, A., 2006: Dél-Dunántúl. - In: Fekete, G. \& Varga, Z. (eds): Magyarország tájainak növényzete és állatvilága. MTA Társadalomkutató Központ, Budapest, pp. 371-393.

Brabec, K., Janecek, B. F. U., Rossaro, B., Spies, M., Bitusik, P., Syrovatka, V. \& Schmidt-Kloiber, A., 2007: Chironomidae Indicator Database. Euro-limpacs project, Workpackage 7 - Indicators of ecosystem health, Task 4. Available from: www.freshwaterecology.info. Date visited: 14.01.2013.

Calle-Martínez, D. \& Casas, J. J., 2006: Chironomid species, stream classification, and water- quality assessment: the case of 2 Iberian Mediterranean mountain regions. - J. N. Am. Benthol. Soc 25: 465-476.

Cranston, P. S., 1982: A key to the larvae of the British Orthocladiinae (Chironomidae). - Freshwater Biological Association, The Ferry House, pp. 1-152.

Cranston, P. S., 1995: Introduction. - In: Armitage, P., Cranston, P. S. \& Pinder, L. C. V. (eds): The Chironomidae. The Biology and Ecology of Nonbiting Midges. - Chapman \& Hall, London, pp. 1-7.
Feminella, J. W., 1996: Comparison of benthic macroinvertebrate assemblages in small streams along a gradient of flow permanence. - J. N. Am. Benthol. Soc. 15: 651-669.

García-Roger, E. M., Sánchez-Montoya, M. M., Gómez, R., Suárez, M. L., Vidal-Abarca, M. R., Latron, J., Rieradevall, M. \& Prat, N., 2011: Do seasonal changes in habitat features influence aquatic macroinvertebrate assemblages in perennial versus temporary Mediterranean streams? - Aquat. Sci. 73: $567-579$.

Gebhardt, A., 1967: A Mecsek hegység állatvilágának térbeli elterjedése élöhelyek szerint. [Spatial distribution of the fauna by habitats in Mecsek Mountains]. - Janus Pannonius Múzeum Évkönyve 12: 7-14.

Giller, P. S. \& Malmqvist, B., 1998: Biology of Rivers and Streams. - Oxford University Press, Oxford, pp. 1-304.

Gooderham, J. P. R., Barmuta, L. A. \& Davies, P. E., 2007: Upstream heterogeneous zones: small stream systems structured by a lack of competence? - J. N. Am. Benthol. Soc. 26: $365-374$.

Grubbs, S. A., 2011: Influence of flow permanence on headwater macroinvertebrate communities in a Cumberland Plateau watershed, USA. - Aquat. Ecol. 45: 185-195.

Heino, J., 2005: Metacommunity patterns of highly diverse stream midges: gradients, chequerboards, and nestedness, or is there only randomness? - Ecol. Entomol. 30: 590- 599.

Heino, J. \& Mykrä, H., 2008: Control of stream insect assemblages: role of spatial configuration and local environmental factors. - Ecol. Entomol. 33: 614-622.

Heino, J., Mykrä, H., Kotanen, J. \& Muotka, T., 2007: Ecological filters and variability in stream macroinvertebrate communities: do taxonomic and functional structure follow the same patch? - Ecography 30: 217-230.

Hijmans, R. J., Cameron, S. E., Parra, J. L., Jones, P. G. \& Jarvis, A., 2005: Very high resolution interpolated climate surfaces for global land areas. - Int. J. Climatol. 25: 19651978.

Janecek, B. F. R., 1998: Diptera: Chironomidae (Zuckmücken). Bestimmung von 4 Larvenstadien mitteleuropäischer Gattungen und österreichischer Arten. - In: Fauna Aquatica Austriaca V. - Kursmaterial, Universität für Bodenkultur, Abteilung Hydrobiologie, Wien. pp. 1-117.

Jombart, T., Devillard, S. \& Balloux, F., 2010: Discriminant analysis of principal components: a new method for the analysis of genetically structured populations. - BMC Genet. 11: 94.

Kevey, B. \& Horvát, A. O., 1986: Die Verbreitung einiger submediterraner Pflanzenarten in Südost-Transdanubien. - Verh. Zool.-Bot. Ges. Österreich 124: 23-40.

Legendre, P. \& Legendre, L., 1998: Numerical ecology. 2nd English edition. - Elsevier Science BV, Amsterdam, pp. 1-853.

Lencioni, V., Marziali, L. \& Rossaro, B., 2012: Chironomids as bioindicators of environmental quality in mountain springs. - Freshwater Science 31: 525-541.

Lencioni, V. \& Rossaro, B., 2005: Microdistribution of chironomids (Diptera: Chironomidae) in Alpine streams: an autoecological perspective. - Hydrobiologia 533: 61-76.

Lindegaard, C. \& Brodersen, K., 1995: Distribution of Chironomidae (Diptera) in River continuum. - In: Cranston, P. C. (ed.): Chironomids. From Gene to Ecosysteme. - CSIRO, Australia, pp. 257-271. 
Marziali, L., Armanini, D. G., Cazzola, M., Erba, S., Toppi, E., Buffagni, A. \& Rossaro, B., 2010: Responses of Chironomid larvae (Insecta, Diptera) to ecological quality in Mediterranean river mesohabitats (South Italy). - River Res. Appl. 26: 1036-1051.

Meusel, H. \& Jäger, E. J., 1989: Ecogeographical differentiation of the Submediterranean deciduous forest flora. - Plant Syst. Evol. 162: 315-329.

Méhes, N., Szivák, I., Csabai, Z. \& Móra, A., 2012: Contribution to the Chironomidae (Diptera) fauna of the Mecsek Mountains. - Acta Biol. Debr. Suppl. Oecol. Hung. 28: 121128.

Milošević, D., Simić, V., Stojković, M. \& Živić, I., 2012: Chironomid faunal composition represented by taxonomic distinctness index reveals environmental change in a lotic system over three decades. - Hydrobiologia 683: 69-82.

Molnár, Zs., Bartha, S., Seregélyes, T., Illyés, E., Botta-Dukát, Z., Tímár, G., Horváth, F., Révész, A., Kun, A., Bölöni, J., Biró, M., Bodonczi, L., Deák, J. Á., Fogarasi, P., Horváth, A., Isépy, I., Karas, L., Kecskés, F., Molnár, Cs., Ortmann-Ajkai, A. \& Rév, Sz., 2007: A grid-based, satellite-image supported, multi-attributed vegetation mapping method (MÉTA). - Folia Geobot. 42: 225-247.

Molnár, Zs. \& Horváth, F., 2008: Natural vegetation based landscape indicators for Hungary I.: Critical review and the basic „MÉTA” indicators. - Tájökológiai Lapok 6: 61-75.

Moog, O. (ed.), 2002: Fauna Aquatica Austriaca. Edition 2002. - Wasserwirtschaftskataster, Bundesministerium für Landund Forstwirtschaft, Vienna.

Móra, A. \& Szivák, I., 2012: Spatial distribution and diversity of chironomid assemblages in a small hilly stream (Diptera: Chironomidae). - Aquat. Insects 34: 127-138.

Móra, A., Csépes, E., Tóth, M., \& Dévai, Gy., 2008: Spatiotemporal variations of macroinvertebrate community in the Tisza River (NE Hungary). - Acta Zool. Acad. Sci. Hung. 54: 181-190.

Oksanen, J., 2011: Multivariate Analysis of Ecological Communities in R: vegan tutorial. - R Documentation, R Foundation for Statistical Computing. Available from: http:// www.R- project.org. Date visited: 29.10.2012.

Orendt, C., 2000: The chironomid communities of woodland springs and spring brooks, severely endangered and impacted ecosystems in a lowland region of eastern Germany (Diptera: Chironomidae). - J. Insect Conserv. 4: 79-91.

R Development Core Team, 2011: R: A language and environment for statistical computing. - R Foundation for Statistical Computing, Vienna, Austria. ISBN 3-900051-07-0. Available from: http://www.R-project.org. Date visited: 29.10.2012.

Roque, F. O., Siqueira, T., Bini, L. M., Ribeiro, M. C., Tambosi, L. R., Ciocheti, G. \& Trivinho-Strixino, S., 2010: Untangling associations between chironomid taxa in Neotropical streams using local and landscape filters. - Freshw. Biol. 55: 847-865.

Pinder, L. C. V., 1995: The habitats of chironomid larvae. In: Armitage, P., Cranston, P. S. \& Pinder, L. C. V. (eds): The Chironomidae. The Biology and Ecology of Non-biting Midges. - Chapman \& Hall, London, pp. 107-135.

Poff, N. L., 1997: Landscape filters and species traits: towards mechanistic understanding and prediction in stream ecology. - J. N. Am. Benthol. Soc 16: 391-409.

Poff, N. L. \& Ward, J. V., 1990: Physical habitat template of lotic system: recovery in the context of historical pattern of spatiotemporal heterogeneity. - Environ. Manage. 14: 629645.
Progar, R. A. \& Moldenke, A. R., 2002: Insect production from temporary and perennially flowing headwater streams in western Oregon. - J. Freshw. Ecol. 17: 391-407.

Puntí, T., Rieradevall, M. \& Prat, N., 2007: Chironomidae assembalges in reference condition Mediterranean streams: environmental factors, seasonal variability, and ecotypes. Fundam. Appl. Limnol. 170: 149-165.

Puntí, T., Rieradevall, M. \& Prat, N., 2009: Environmental factors, spatial variation, and specific requirements of Chironomidae in Mediterranean reference streams. - J. N. Am. Benthol. Soc. 28: 247-265.

Raposeiro, P. M., Costa, A. C. \& Hughes, S. J., 2011: Environmental factors - spatial and temporal variation of chironomid communities in oceanic island streams (Azores archipelago). - Ann. Limnol. 47: 325-338.

Raunio, J., Heino, J. \& Paasivirta, L., 2011: Non-biting midges in biodiversity conservation and environmental assessment: Findings from boreal freshwater ecosystems. - Ecol. Indic. 11: 1057-1064.

Rosa, B. F. J. V., Oliveira, V. C. \& Alves, R. G., 2011: Structure and spatial distribution of the Chironomidae community in mesohabitats in a first order stream at the Poço D'Anta Municipal Biological Reserve in Brazil. - J. Insect Sci. 11: 36.

Sæther, O. A., Ashe, P. \& Murray, D. A., 2000: A.6. Family Chironomidae. - In: Papp, L. \& Darvas, B. (eds): Contribution to a manual of Palaearctic Diptera. Appendix. - Science Herald, Budapest, pp. 113-334.

Sæther, O. A. \& Spies, M., 2011: Fauna Europaea: Chironomidae. - In: Beuk, P. \& Pape, T. (eds): Fauna Europaea: Diptera, Nematocera. Fauna Europaea version 2.4. Available from: http://www.faunaeur.org. Date visited: 29.10.2012.

Schmedtje, U. \& Colling, M., 1996: Ökologische Typisierung der aquatischen Makrofauna. - Informationsberichte des Bayerischen Landesamtes für Wasserwirtschaft 4: 96.

Schneider, S. C., Lawinczak, A. E., Picińska-Faltynowicz, J. \& Szoszkiewicz, K., 2012: Do macrophytes, diatoms and nondiatom algae give redundant information? Results from a case study in Poland. - Limnologica 42: 204-211.

Siqueira, T., Bini, L., Cianciaruso, M., Roque, F. \& TrivinhoStrixino, S., 2009: The role of niche measures in explaining the abundance-distribution relationship in tropical lotic chironomids. - Hydrobiologia 636: 163-172.

Southwood, T. R. E., 1977: Habitat, the templet for ecological strategies? - J. Anim. Ecol. 46: 337-365.

Statzner, B., Resh, V. H. \& Dolédec, S., 1994: Ecology of the upper Rhône river: a test of habitat templet theories. Freshw. Biol. 31: 253-554.

Svensson, B. S., 1979: Pupation, emergence and fecundity of phoretic Epoicocladius ephemerae (Chironomidae). - Holarctic Ecol. 2: 41-50.

Szivák, I., Deák, Cs., Kálmán, Z., Soós, N., Mauchart, P., Lőkkös, A., Rozner, Gy., Móra, A. \& Csabai, Z., 2010: Contribution to the aquatic macroinvertebrate fauna of the Mountains Mecsek with the first record of Limnius opacus P. J. W. Müller, 1806: Hungary. - Acta Biol. Debr. Suppl. Oecol. Hung. 21: 197-222.

Townsend, C. R., 1989: The patch dynamics concept of stream community ecology. - J. N. Am. Benthol. Soc. 8: 36-50.

Townsend, C. R. \& Hildrew, A. C., 1994: Species traits in relation to a habitat templet for river system. - Freshw. Biol. 31: $265-275$. 
Townsend, C. R., Dolédec, S., \& Scarsbrook, M. R., 1997: Species traits in relation to temporal and spatial heterogeneity in streams: a test of habitat templet theory. - Freshw. Biol. 37: 367-387.

Vallenduuk, H. J. \& Moller Pillot, H. K. M., 2007: Chironomidae larvae. General ecology and Tanypodinae. - KNNV Publishing, Zeist, The Netherlands, pp. 1-144.

Vannote, R. L., Minshall, G. W., Cummins, K. W., Sedell, J. R. \& Cushing, C. E., 1980: The river continuum concept. - Can. J. Fish. Aquat. Sci. 21: 517-531.
Verberk, W. C. E. P., Siepel, H \& Esselink, H., 2008: Life-history strategies in freshwater macroinvertebrates. - Freshw. Biol. 53: 1722-1738.

Wiederholm, T. (ed.), 1983: Chironomidae of the Holarctic region. Keys and diagnoses. Part Larvae. - Entomol. Scand. Suppl. 19: 1-457.

Winemiller, K. O., Flecker, A. S. \& Hoeinghaus, D. J., 2010: Patch dynamics and environmental heterogeneity in lotic ecosystems. - J. N. Am. Benthol. Soc. 29: 84-99.

Submitted: 30 October 2012; accepted: 1 April 2013.

Appendix 1. Collected chironomid species, their abbreviation and distribution according to the two areas characterized by different bedrock. Abbrev.: S - area having sandstone bedrock, L - area having limestone bedrock. Taxa marked '*' were omitted from statistical analysis due to their relative abundance less than $0.2 \%$.

\begin{tabular}{|c|c|c|}
\hline Taxon & Codes & Bedrock type \\
\hline Apsectrotanypus trifascipennis (Zetterstedt, 1838) & A_tri & $\mathrm{S}$ \\
\hline Brillia bifida (Kieffer, 1909) & B_bif & S \\
\hline Chironomus sp. ${ }^{*}$ & Chi_sp & $\mathrm{S}$ \\
\hline Conchapelopia sp. & Con_sp & $\mathrm{S}$ \\
\hline Corynoneura sp.* & Cor_sp & $\mathrm{S}$ \\
\hline Cricotopus (Isocladius) sp.* & Cri sp & $\mathrm{S}$ \\
\hline Diamesa cinerella gr. Meigen, 1835 & D_cin & $\mathrm{S}$ \\
\hline Diplocladius cultriger Kieffer, 1908* & D_cul & $\mathrm{S}$ \\
\hline Epoicocladius ephemerae (Kieffer, 1924) & E_eph & $\mathrm{L}$ \\
\hline Macropelopia nebulosa (Meigen, 1804)* & Ma_neb & $\mathrm{L}$ \\
\hline Macropelopia notata (Meigen, 1818)* & Ma_not & $\mathrm{S}$ \\
\hline Macropelopia sp. & Ma_sp & $\mathrm{S}$ \\
\hline Micropsectra notescens (Walker, 1856) & Mi_not & $\mathrm{S}$ \\
\hline Microtendipes chloris (Meigen, 1818) & Mi_chl & $\mathrm{L}, \mathrm{S}$ \\
\hline Microtendipes pedellus gr. (De Geer, 1776) & Mi_ped & $\mathrm{L}, \mathrm{S}$ \\
\hline Natarsia sp. & Nat_sp & $\mathrm{S}$ \\
\hline Odontomesa fulva (Kieffer, 1919) & $\mathrm{O}$ ful & $\mathrm{S}$ \\
\hline Orthocladius (Orthocladius) sp.* & Ort_O & $\mathrm{S}$ \\
\hline Orthocladius sp. & Ort_sp & $\mathrm{S}$ \\
\hline Orthocladius thienemanni Kieffer, 1906 & Ort_thi & $\mathrm{L}, \mathrm{S}$ \\
\hline Parametriocnemus stylatus (Spärck, 1923) & P_sty & $\mathrm{S}$ \\
\hline Paratrichocladius skirwithensis (Edwards, 1929) & P_ski & $\mathrm{L}, \mathrm{S}$ \\
\hline Paratrissocladius excerptus (Walker, 1856) & P_exc & $\mathrm{S}$ \\
\hline Polypedilum convictum (Walker, 1856) & P_con & $\mathrm{L}, \mathrm{S}$ \\
\hline Polypedilum pedestre (Meigen, 1830) & P_ped & $\mathrm{S}$ \\
\hline Polypedilum scalaenum (Schrank, 1803) & P_sca & $\mathrm{L}, \mathrm{S}$ \\
\hline Polypedilum sp.* & P_sp & $\mathrm{S}$ \\
\hline Polypedilum uncinatum (Goetghebuer, 1921)* & $\mathrm{P}$ unc & $\mathrm{L}$ \\
\hline Procladius (Holotanypus) sp.* & Pro_sp & $\mathrm{L}$ \\
\hline Prodiamesa olivacea (Meigen, 1818) & Pro_oli & $\mathrm{S}$ \\
\hline Rheocricotopus atripes (Kieffer, 1913)* & Rc_atr & $\mathrm{S}$ \\
\hline Rheocricotopus effusus (Walker, 1856)* & Rc_eff & $\mathrm{S}$ \\
\hline Rheocricotopus fuscipes (Kieffer, 1909) & Rc_fus & $\mathrm{L}, \mathrm{S}$ \\
\hline Rheopelopia sp. & Rp_sp & $\mathrm{S}$ \\
\hline Rheotanytarsus sp. & Rt_sp & $\mathrm{L}$ \\
\hline Zavrelimyia sp. & Zav_sp & $\mathrm{L}, \mathrm{S}$ \\
\hline
\end{tabular}

